УДК 006.015.5

\title{
ДОСЛІДЖЕННЯ ТА АНАЛІЗ СИСТЕМИ УПРАВЛІННЯ ЯКІСТЮ МЕТРОЛОГІЧНИХ РОБІТ
}

Д-р техн. наук В.М. Остапчук, І.А. Манушина

\section{ИССЛЕДОВАНИЕ И АНАЛИЗ СИСТЕМЫ УПРАВЛЕНИЯ КАЧЕСТВОМ МЕТРОЛОГИЧЕСКИХ РАБОТ}

Д-р тех. наук В.Н. Остапчук, И.А. Манушина

\section{INVESTIGATION AND ANALYSIS OF QUALITY MANAGEMENT METROLOGICAL WORKS}

\author{
Dr. of techn. sciences V.N. Ostapchuk, I.A. Manushyna
}

Стабільне та ефективне функціонування залізничного транспорту України, інтеграція країни у загальносвітову економічну системи потребують вирішення питань розробки та впровадження системі управління якістю метрологічних робіт як важливої ланки в постійному поліпшенні якості та підвищенні задоволення спожсивачів, дієвість якої можсливо дослідити за допомогою прочесної моделі.

Ключові слова: метрологічні роботи, система управління якістю, моделювання, модель, процесний підхід.

Стабильное и эффективное функиионирование железнодорожного транспорта Украины, интеграция страны во всемирную экономическую систему требуют решения вопросов разработки и внедрения системы управления качеством метрологических работ, как важного звена в постоянном улучшении качества и удовлетворения потребителей, действенность которого можно исследовать с помощью прочессной модели.

Ключевые слова: метрологические работы, система управления качеством, моделирование, модель, проиессный подход.

A stable and efficient operation of railway transport of Ukraine, the country's integration into the global economic system need to be addressed in the development and implementation of quality 
management system of metrological work as an important link in the continuous improvement of quality and increase customer satisfaction, the effectiveness of which can explore using the process model.

Keywords: metrology work, quality management system, modeling, the model, process approach.

Актуальність

дослідження. Залізничний транспорт - одна 3 найбільш важливих галузей народного господарства України. Без транспорту неможлива інтеграція України у загальносвітову економічну систему. Розбудова економіки нашої країни та намагання ії піднесення до світового рівня висуває перед суб'єктами господарювання ряд важливих завдань, що потребують вирішення. Одне 3 найважливіших конкурентоспроможності українських виробників товарів і послуг, їх вихід на європейський та світовий ринки.

Забезпечуючи народногосподарський комплекс вантажними i пасажирськими перевезеннями, залізничний транспорт формує тісні взаємозв'язки з усіма галузями народного господарства країни та $\epsilon$ важливою ланкою у розвитку експортних відносин. У цьому зв'язку набуває особливого значення проблема розробки та впровадження дійових методів управління витратами на забезпечення якості продукції (надання послуг). У ринковій економіці проблема якості $\epsilon$ найважливішим чинником підвищення рівня життя, економічної, соціальної й екологічної безпеки. Це передбачає реалізацію цілого комплексу заходів структурноорганізаційного, техніко-інноваційного та правового характеру. Серед них і адаптація національної системи стандартизації, метрології та сертифікації (технічних стандартів, процедур та органів 3 оцінки відповідності тощо) до системи технічного регулювання Європейського Союзу, що вимагає поглибленого дослідження останньої [1].

Незважаючи на те, що метрологічна діяльність - одна 3 найбільш консервативних сфер виробництва, а положення, які iї регламентують, в найменшій мірі піддаються зміні і завжди підпорядковані одній меті - забезпеченню єдності вимірювань, повсюдне впровадження інформаційних технологій торкнулося i процесів метрологічного забезпечення.

Метрологічна діяльність зазнала серйозних змін $[1,8]$, так як змінилися основи виробництва: засоби вимірювань інтегруються 3 технологією виробництва, випробуваннями (автоматизація випробувань на основі застосування сучасних інформаційно - вимірювальних систем), підвищується точність засобів вимірювань, автоматизуються процеси калібрування.

Постановка проблеми. Щоб бути конкурентоспроможними i вести успішну економічну діяльність, підприємствам необхідно застосовувати високоефективні і результативні системи управління якістю метрологічних робіт (далі - СУЯМР) [4, 6, $9,10]$. Використання таких систем повинно вести до постійного поліпшення якості та підвищення задоволеності споживачів. СУЯМР може бути ефективною тільки за умови, коли вона функціонує одночасно і в тісній взаємодії 3 усіма підрозділами підприємства, які впливають на якість продукції.

Основна частина. Найважливішою ланкою забезпечення якості метрологічних робіт на підприємстві $\epsilon$ метрологічна служба. Управління якістю продукції неможливе без метрологічного забезпечення вимірювань $[3,5,8]$, яке відрізняється унікальними можливостями отримання кількісної інформації про матеріальні та енергетичні ресурси, якість матеріалів i сировини, про стан навколишнього середовища, про безпеку i 
охорону здоров'я людей i, відповідно, про якість процесів і продукції.

У СУЯМР на метрологічну службу покладено відповідальність за управління засобами моніторингу та вимірювань [5]. Щоб діяльність метрологічної служби підприємства повністю задовольняла вимоги державних та міжнародних стандартів до процедур управління контрольним, вимірювальним та випробувальним обладнанням, необхідно всередині системи управління якістю підприємства розробити і підтримувати в робочому стані СУЯМР, яка б документально регламентувала основні процедури виконання окремих видів діяльності 3 метрологічного забезпечення вимірювань.

Якість метрологічних робіт визначається дією багатьох випадкових, місцевих i суб'єктивних факторів. Для попередження впливу цих факторів на рівень якості необхідна система управління якістю метрологічних робіт. При цьому потрібні не окремі розрізнені й епізодичні зусилля, а сукупність заходів постійного впливу на процес створення продукту 3 метою підтримки відповідного рівня якості.

Моделювання реальної СУЯМР засноване на застосуванні системного підходу, тобто шляхом розгляду підприємства як системи ієрархічних i взаємопов'язаних процесів на всіх рівнях підприємства, та системного аналізу. У багатьох аспектах системний аналіз $\epsilon$ найбільш важкою частиною дослідження. Це не тільки технічні труднощі аналізу, політичні труднощі, а й проблеми, пов'язані 3 необхідністю спілкування в умовах, коли люди, що володіють різним рівнем освіти, різними поглядами на світ i різним словниковим запасом, повинні працювати спільно.

Основною задачею побудови моделей при дослідженні систем управління $\epsilon$ створення ефективних графічних методів, що забезпечують отримання ясного та загального подання системи. Графічні подання систем дозволяють усвідомити, як поєднуються між собою компоненти системи i як задовольняються потреби користувачів. Без такого інструментарію для структурного системного аналізу немає можливості показати логічні функції i потреби системи, які лежать в основі.

Користуючись моделлю, можна провести експеримент, вивчати можливу поведінку об'єкта при змінах факторів i параметрів зовнішнього i внутрішнього середовища, настанні тих чи інших подій, здійсненні об'єктом або суб'єктом управління певних дій. Всі процеси управління i виробничий цикл підприємства подані як структура взаємопов'язаних процесів (функцій) [2].

Модель системи якості, що грунтується на процесах й ілюструє розглянуті в цьому розділі питання та зв'язки між ними, подана на рис. 1 у вигляді чотирьох блоків взаємопов'язаних між собою процесів:

- відповідальність керівництва;

- управління ресурсами;

- створення продукту;

- вимірювання, аналіз і поліпшення.

Цей рисунок показує, що зацікавленим сторонам відведено важливу роль у визначенні вимог як до входів, так і виходів. Для відображення ступеня задоволеності споживача потрібно оцінювати інформацію, пов'язану 3 його думкою щодо того, чи виконала організація його вимоги.

Перевагою процесного підходу $\epsilon$ забезпечуваний ним неперервний контроль зв'язків окремих процесів у межах системи процесів, а також їхніх сполучень та взаємодій. Застосування процесного підходу в межах СУЯМР підкреслює важливість: розуміння виконання вимог; необхідність розглядати процеси 3 погляду створення додаткових цінностей; отримання результатів функціонування процесу та його ефективності; постійного поліпшення процесу об'єктивних вимірювань. 


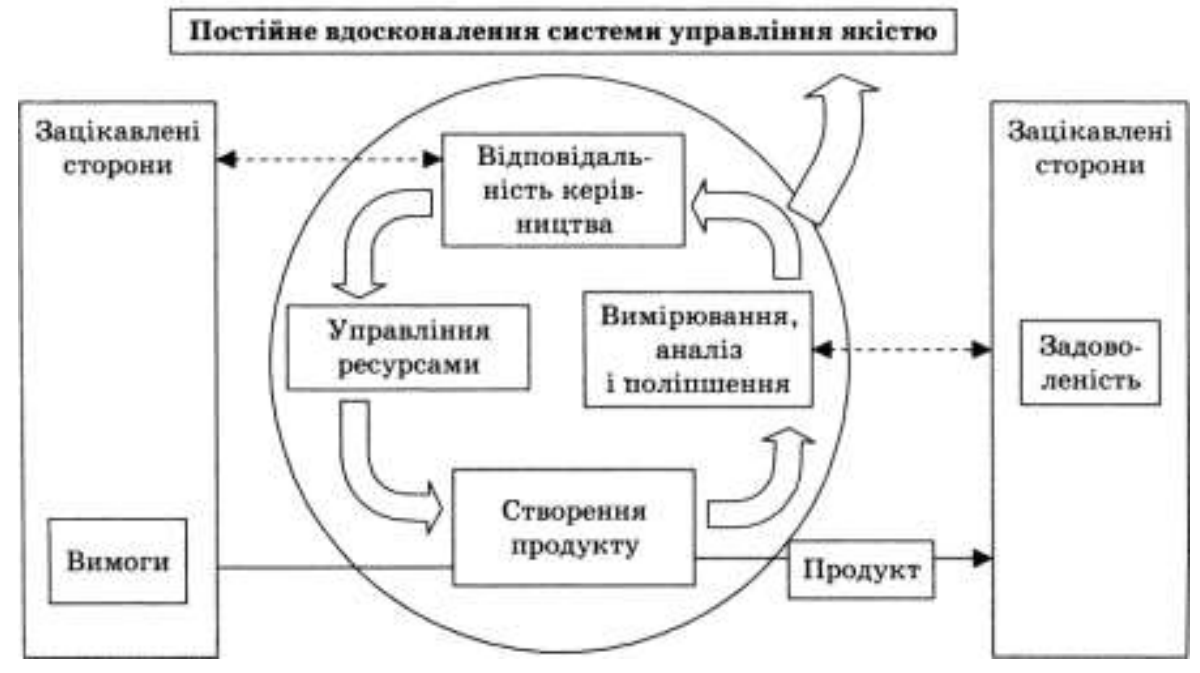

Рис. 1. Модель системи якості, в основу якої покладено процеси

Застосування процесного підходу [3] вимагає розгляду, насамперед, сукупності виконуваних на підприємстві вимірювань як локально упорядкованого процесу, моделлю якого, в першому наближенні, можна вважати випадковий потік. Потік вимірювань має складну структуру: він повинен бути впорядкований в просторі (вимірювання здійснюються в певних підрозділах) і в часі (вимірювання входять складовою частиною в плановані етапи життєвого циклу продукції), однак прив'язка вимірювань до точок простору і моментів часу не абсолютна, а схильна до природних коливань у зв'язку з мінливістю конкретних умов. Для метрологічної служби, що розглядає вимірювання інтегрально в рамках всього підприємства, потік вимірювань виявляється нерегулярним, тому управління вимірами являє собою не просту функцію. Основними інструментами управління служать розробка та реалізація відповідних стандартів підприємства, а також проведення процедур метрологічного обслуговування технічних засобів (методик виконання вимірювань і 3В). На першому (верхньому) рівні організації процесів метрологічної діяльності на підприємстві визначається процес М3. У ньому виділяють підпроцеси, у ролі яких природно встановити процеси виконання функцій М3. Таким чином, визначається структура, яка подана на рис. 2 , де КД конструкторська документація, ТД - технологічна, ЗКн - засоби контролю, ЗВип випробувань.

Зазначена структура не є єдино можливою. Замість змішаного функціонально-об'єктного принципу виділення процесів можна послідовно використовувати тільки функціональний принцип. В цьому випадку підпроцесами 3го рівня для МЗ були б, наприклад, «Організація МЗ», «Аналіз документів», «Документування та реалізація результатів МЗ». Аналогічно, для процесу «Управління засобами» в ролі підпроцесів виступали б «Визначення потреби i оснащення засобами», «Процедури підтвердження відповідності», «Обслуговування та облік коштів», «Списання та утилізація засобів». Іншими словами, були б об'єднані універсальними функціями всі категорії засобів, а відмінності цих категорій враховані особливостями конкретних процедур виконання зазначених функцій. Глибина структурування (кількість рівнів, або підпроцесів) може бути різною залежно від розмірів підприємства $\mathrm{i}$ доступних ресурсів. 


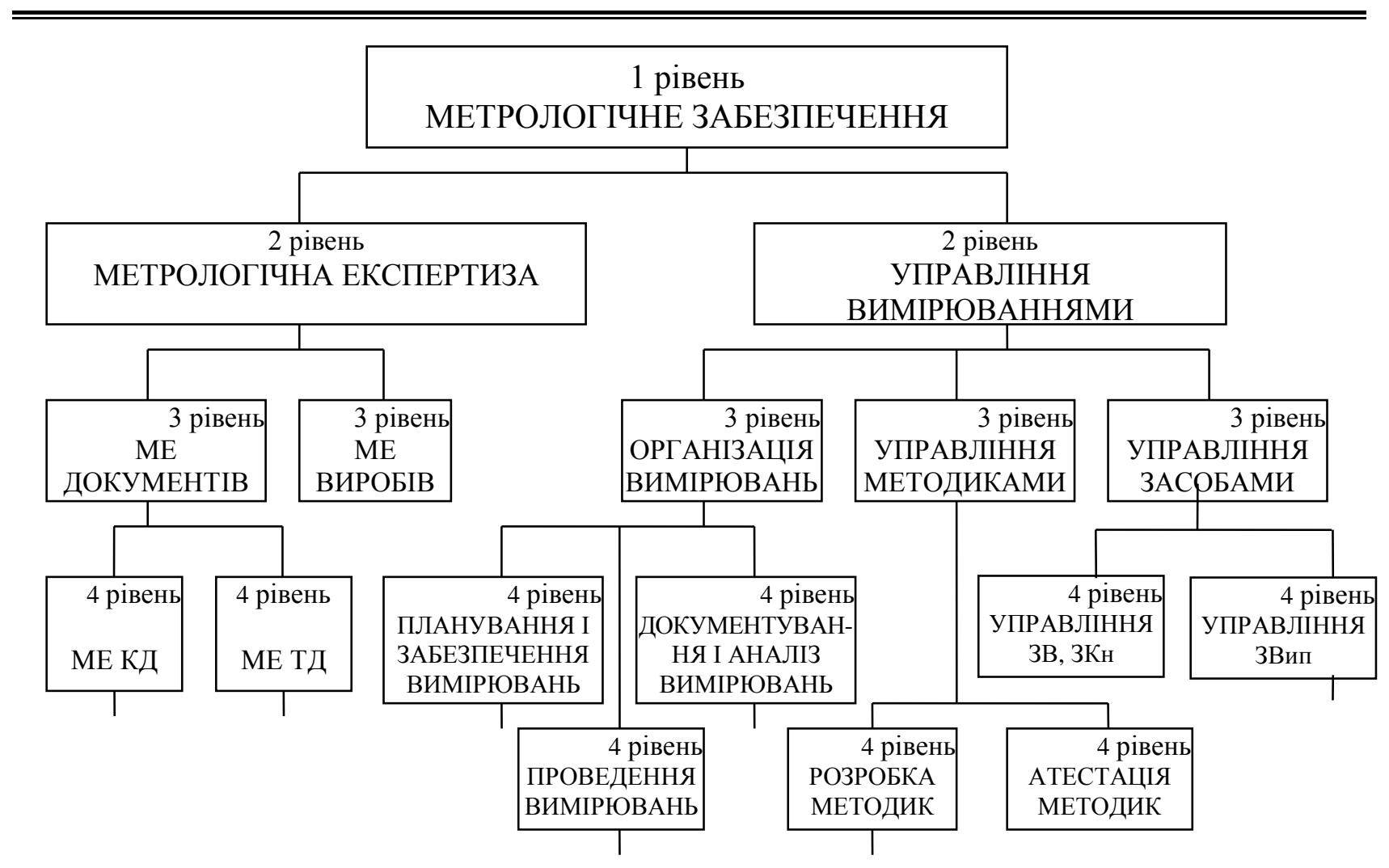

Рис. 2. Структура процесу М3

Весь комплекс заходів щодо створення та впровадження системи управління якістю завершується процесом сертифікації системи підприємства на відповідність вимогам стандарту ICO 9000.

Висновки.

Застосовуючи моделювання, можна досягти необхідних результатів у господарській діяльності підприємства. При цьому:

1. Побудова моделі відноситься до числа системних завдань, при вирішенні яких синтезують рішення на базі величезного числа вихідних даних, на основі пропозицій великих колективів фахівців.

2. Використання системного підходу в цих умовах дозволяє не тільки побудувати модель реального об'єкта, але і на базі цієї моделі вибрати необхідну кількість керуючої інформації в реальній системі, оцінити показники іiї функціонування і тим самим на базі моделювання знайти найбільш ефективний варіант побудови i вигідний режим функціонування реальної системи.

3. При моделюванні необхідно забезпечити максимальну ефективність моделі системи, яка визначається як деяка різниця між якимись показниками результатів, отриманих у результаті експлуатації моделі, і тими витратами, які були вкладені в іiі розробку і створення.

\section{Список використаних джерел}

1. Біла книга. Про політику адаптації вітчизняного законодавства у галузі норм i стандартів до європейських вимог [Текст]. - К.: Держспоживстандарт України, 2006 - 65 с.

2. Теория управления [Текст]: учеб. под общей ред. д.э.н., проф. А. Л. Гапоненко, д.э.н., профессора А.П. Панкрухина. - М.: Издательство РАГС, 2003. - 558 с. 
3. Грановский, В.А. Метрологическое обеспечение на промышленном предприятии: проблемы и решения [Текст] / В.А. Грановский // Измерения. Контроль. Автоматизация: состояние, проблемы, перспективы. - 2009. - № 8. - С. 94-108.

4. Данилец, Е.В. Имитационное моделирование систем управления качеством в экономике [Текст] / Е.В. Данилец // ААЭКС Экономика научно-технического прогресса. 2008. - № 2(22). - C. 197-208.

5. ДСТУ ISO 9001-2009 Системи управління якістю. Вимоги [Текст].

6. Круглов, М.Г. Менеджмент систем качества [Текст]: учеб. пособие / М.Г. Круглов, С.К. Сергеев, В.А. Такташов [и др.]. - М.: ИПК Издательство стандартов, 1997. - 368 с.

8. Лифиц, И.М. Основы стандартизации, метрологии, сертификации [Текст] / И.М. Лифиц. - М.: Юрайт, 2001. - 613 с.

9. Ребрин, Ю.И. Управление качеством [Текст]: учеб. пособие / Ю.И. Ребрин. Таганрог: Изд-во ТРТУ, 2004. - 174 с.

10. Шаповал, М.I. Менеджмент якості [Текст]: навч. посібник / М.I. Шаповал. - К., 2007. - C. 471

Остапчук Віктор Миколайович, д-р техн. наук, професор кафедри матеріалів та технології виготовлення виробів транспортного призначення.

Манушина Ірина Анатоліївна.

Dr. of techn. sciences Ostapchuk V., Manushyna I.A. 